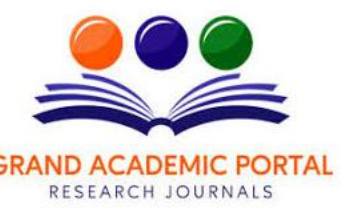

\title{
GENDERING EMOTIONS: CONSOLIDATING PATRIARCHY
}

\author{
Emelia Noronha \\ Assistant Professor, Prahladrai Dalmia Lions College of Commerce \& Economics, Mumbai, India. \\ emelia.n@rediffmail.com

\begin{abstract}
This paper attempts to look at the ways in which emotions are gendered. Emotions of anger and love the two emotions that are discussed in the paper with reference to women in India depicted in the Indian epics. The study aims to analyze the politics of gendered emotions as portrayed in Indian literature. The resurgent interest in characters of Sita and Draupadi in Indian novels is analyzed. The paper tries to understand how self-gratification or pleasure is an emotion that does not find adequate place in the realm of the Indian epic.
\end{abstract}

Keywords: feminism, women, emotions, gender

\section{INTRODUCTION}

Emotions one would assume are not gender specific. All human beings are endowed with them. The socializing process is crucial in determining how important their role is in the formation of selves. This paper looks at the expression of anger and love in Yajnaseni: The Story of Draupadi by Pratibha Raya, The Palace of Illusions by Chitra Banerjee Divakaruni, Sita's Sister by Kavita Kané and The Liberation of Sita by Volga. This paper takes examples of women and their depictions in works that recreate or re-vision the great Indian epics - either in totality or as excerpts. The resurgence in the interest in the characters of Sita and Draupadi are crucial. The two epics have been the iconic texts that have set the rules and lessons in "dharma" for the Indian masses. Earlier through the oral tradition and drama - the Ram Leela performances and later through the popular culture film and television - the iconic role model for every Indian woman has been Sita. Draupadi has been the 'problematic' woman, a paragon of resistance and boldness. The stark difference between the two characters even if not articulated vehemently is indicated in the fact that we would find Indian parents eager to name their girl child - Sita, but one rarely finds parents naming their child "Draupadi".

\section{REVIEW OF LITERATURE}

Gender and Emotions in Medieval and Early modern Europe : Destroying Order, Structuring Order edited by Susan Broomhall brings together explorations on the manner in which gender and emotions operated in medieval and modern Europe to "effect real or perceived forms of order and disorder". (Broomhall, 1). Susan notes that gender research is a vital and dynamic area of research that offers much to the historical emotional expressions and experiences. Social order and stability was often premised on control of emotional articulations both for men and women.

Catherine A. Lutz, in 'Feminist Emotions', (Lutz, 197) distinguishes six types of / feminist engagement with emotions: feminist re readings / developmental emotion dynamics, emotion as authentic femininity, emotion as epistemic resource, emotion as cultural discourses on power, emotion as social labor, and emotion as life on the social margins.

Stephanie A. Shields' study Speaking from the Heart: Gender and the social Meaning of Emotion elaborates on "how the naturalizing of emotions has consequences for gender and gender relations are constructed in the course of daily life. Because concepts of emotion and emotionality are differently applied to women and men, the gendered emotion scheme inevitably connects to systems of power." (Shields, 9)

Emotions are not looked upon as something that is solely a personal attribute but it is seen as a social construct. As Simone de Beauvoir famously claimed that one is not born, but rather becomes a woman similarly the emotions are part of the cultural practices that attach themselves with certain genders and thereby empower or divest them of power depending upon the set of emotional attributes one possesses/lacks in consonance /dissonance with the existing social structural rules and regulations. Emotions are not part and parcel of one's individuality but it is the performity of these emotions that makes ones identity, even gender. Judith Butler gives prime importance to the performity of genders. Butler asserts that gender is "instituted through the stylization of of the body, hence ... body gestures, movements and enactments of various kinds constitute the illusion of an abiding gendered self". (Butler, 519-531) It is through the stylized repetition of such acts that the gendered body is produced. It is through a "|series of acts which are renewed, revised, and consolidated through time" (Butler, 523) that a body becomes a gender. The acts thus a sedimentation of 


\section{$\stackrel{0}{=}$ \\ A GLOBAL JOURNAL OF HUMANITIES}

GRAND ACADEMIC PORTAL RESEARCH JOURNALS
( ISSN - 2581-5857)

Impact Factor: SJIF - 5.171, IIFS - 5.125

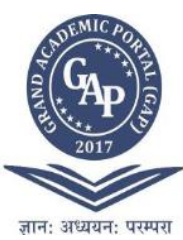

The character of Bhim, on the other hand, in The Palace of Illusions is known for his anger and is never berated for it. In fact it is a quality that causes other to be in awe of the power of his anger and gives him superiority and therefore one does not mess around with him. In the same novel we have Draupadi aware of the importance of anger; though she has learnt to contain it; at occasions she regales in its display as she is aware of the power it wields, "it's never a good idea to let one's husbands grow complacent. My displays of temper ensured that the Pandavs continued to regard me with healthy respect." (Divakaruni, 263) Light displays of temper are required to assert oneself and that is what Draupadi uses as a powerful tool of asserting herself. But anger along with desire for retribution - vengeance is a lethal combination. One also has to keep in mind what makes Draupadi a transgress in the qualities that are feminine - she is "born of fire" and has had never to undergo the process of growing up -and getting acculturated in the societal norms, she was born from the fire after the birth of her brother Dhristadyumna, as against the feeble five year old boy Draupadi is described as - " as dark as he was fair, as hasty as he was calm. Coughing from the smoke, tripping over the hem of your sari, grabbing for his hand and almost sending him tumbling" the initial years of growing into a girl were skipped for Draupadi.

\section{THE EMOTION OF LOVE}

Sita of the Ramayana is the epitome of the ideal woman, the role model for Indian womanhood, a signifier of chastity, pure love and sacrifice. But it Sita of The Liberation of Sita is who is problematic, for she is the Sita that questions. Sita questions the male patriarchal society "Do women exist only to be used by men to settle their scores?" And in Volga's novel it is not Sita who symbolises love but Surpnakha, the sister of Ravana who had yearned for "love" and had put forth her proposal of love to Rama, but in return was disfigured and humiliated. Her humiliation - the destruction of her nose - her beauty, the prime adornment of beauty being destroyed, was left as a relic of shame and ugliness, an epitome of rejection that was to be looked down upon, a beauty scorned and destroyed for life. Who is to be blamed? When the minimum punishment for the "acid thrower" in India today is enforcement of Section 326 A in the Indian Penal Code - 10 years of imprisonment how can then one condole the permanent disfigurement of Surpnakha. Thus revenge is the prime reason for the angry brother, Ravana to abduct Sita. In The Liberation of Sita we have Sita meeting Surpnakha in forest, where Sita is left forlorn by her "Maryada Purushottam" husband and ruler Rama. Surpnakha explains her plight after her disfigurement - "My life was unbearable in the initial days after my mutilation. I loathed my appearance. I hated myself. . My heart burned with pain and anger every single day. How much I cursed Sri Rama, his brother Lakshmana and you! I spewed venom at all of you. There was not a trace of love left in me; hate had gripped my heart... I became a walking volcano. A stormy sea of grief." (Volga et al. 13) But we are told that Surpnakha did not wallow in self pity or allow anger to get control over her. She tells Sita of how she overpowered her anger through love: "to come out of that spitefulness, to love beauty once again, to understand the essence of form and formlessness - I had to wage a battle against myself. My only collaborator in that battle was this infinite nature." (Volga et al.15)

She further elaborates that "I had no guru in this matter. I pursued it on my own. I searched every particle in nature, and in the course of that search, my own vision changed. Everything began to look beautiful in my eyes. I who hated everything including myself, began to love everything including myself." (Volga et al.15) Thus love when disregarded from the connection to the masculine perspective liberated Surpnakha, she even finds a partner for herself who loves her not for her beauty but for who she is - a human being full of love.

In the classical Indian scenario the rasas - aesthetic experience - put forth by Bharata Muni's rasa theory in Natyashastra are Śrngārah that coordinates with romance, love and attractiveness; Hāsyam is Laughter, mirth or comedy; Raudram is Fury; Kārunyam is Compassion or mercy; Bībhatsam is Disgust or aversion; Bhayānakam is Horror or terror; Veeram is Heroism and Adbhutam is wonder or amazement. The bhava or emotions (a crude translation, but a useful one) that these rasas generate are - Rati (Love), Hasya (Mirth), Soka (Sorrow), Krodha (Anger), Utsaha (Energy), Bhaya (Terror), Jugupsa (Disgust) and Vismaya (Astonishment). Rati refers to the deep rooted emotion of Amor (God of Love) existing in the mind of a man by reference to a woman, or in the mind of a woman by reference to a man. It has many forms from Raga, passing through Anuraga, Prem, Sneha, Mana. The Śrngārah rasa that evokes the bhava of Rati (Love), is the emotion that is suited to the amorous relationship that lovers share. Kalidasa's Abhijnanashakuntala is a work devoted to the Śrngārah rasa. The love of Dushyant for Shakuntala and vice-versa reflects the prominent emotion of love. Malati Madhava the second play of Bhavabhuti, the story of two lovers Malthi and Madhav, is totally in keeping with the rendition of the Śrngārah rasa. These were plays written in keeping with the rasas in mind. The epics the Ramayana and the Mahabharata therefore have no place for such lowly emotional outpourings.

The element of love as noted in Bharat Muni is present in the novel Yajnaseni: The story of Draupadi in relation to Draupadi and Krishna. The love in its 'real 'essence as all encompassing form that gives divine joy, is otherwise absent in relation to Arjun, which Yudhisthir proclaims to be the reason of Draupadi's downfall. The bhava of Rati is evoked in bits and pieces in the novel but does not loom large in the novel as the trajectory of the novel lies elsewhere.

Krishna stands for love for Draupadi in The Palace of Illusions - 


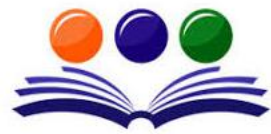 \\ A GLOBAL JOURNAL OF HUMANITIES}

GRAND ACADEMIC PORTAL RESEARCH JOURNALS
( ISSN - 2581-5857)

Impact Factor: SJIF - 5.171, IIFS - 5.125

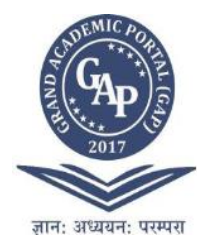

Dharma is evoked at every crucial moment of decision making. In Pratibha Raya's Yajnaseni: the story of Draupadi Arjun rationalizes to Draupadi,

"My supreme moments of happiness with you have gone by. The time that I have been able to have you solely by myself, that remains the most precious period of my life. The rest of life that remains in our hands is solely for the sake of preserving dharma, preserving civilization, for the welfare of the world. Therefore how can you lose faith in yourself? Now you are longer your own; you belong to the world! Why should I blame you for having offered yourself for the preservation of dharma in the world?" (Raya 80)

Yudhishthir exhorts: Man's greatest dharma is obeying the commands of his elders. . . Mother is our all powerful governor. Obeying her command, if all five of us marry Krishnaa it will only be following dharma for us." (Raya 67)

Krishna giving an explanation to Drupad says, "for the preservation of dharma in Aryavart today, it is necessary for the five Pandavas to be strung together. Only your beautiful daughter Krishna is capable of keeping them tied together. .. . even if it is the five Pandavs who will establish dharma in Aryavart, Krishnaa's noble role will be recorded in sacred letters in the annals of time." (Raya 68)

Taking upon herself the cudgels of preservation of dharma Draupadi too rationalizes her decision for the sake of preservation of dharma, "Should Draupadi alone, conserving her happiness honour and pride more important, disregarding the views of them all, invite the scorn and curses of the whole world? "(Raya 81)

Before accepting her marriage to the five Pandavs Draupadi in Pratibha Raya's Yajnaseni takes the decision: I had comprehended this much that for a greater cause a lesser interest could be sacrificed. If I did not take five husbands then my renown as a sati would increase, but thereby Mother's words would not be honoured, the Pandavs would not be able to safeguard truth. the establishment of dharma on earth would be hindered. Therefore, I should sacrifice myself. I , Yajnaseni, born of sacrificial altar for the preservation of dharma! ... then in their dharmayajna let this body become an c! In reality what was this body? ... So let everybody be happy getting this body. Let them be united. Why should I be an obstacle?" (Raya 63)

The metaphor of being offered as oblation is seen throughout the novel. Draupadi born of the sacrificial fire is not to be afraid of the very element she is born from but will not be the fire that consumes others but like the "ghee " offered in oblation - both in body and spirit - will be sacrificed in the cause of dharma.

One would assume that it is women in the third world that are not given the freedom to owning an emotion like anger and pleasure as the culture they are part of has not yet broken the shackles of patriarchy. But this is a fallacy. The infamous tweet: "Greta must work on her Anger Management problem, then go to a good old fashioned movie with a friend! Chill Greta, Chill!", the president of the United States ridiculing Greta Thunberg's nomination as the Time's 2019 Person of the Year. Nov 4, 2017 is well known. Her agitation against the ruthless ravaging of our environment is seen as a useless ranting of a 'girl' needing lessons in anger management. c hits the headlines saying she has been "waiting to feel less angry" before discussing sexual harassment issues in Hollywood. Later she claims that Harvey Weinstein assaulted her and that director Quentin Tarantino sexually misbehaved with her. A well established Hollywood actress had to contain her anger and wait for an opportune moment to come out with the truth of being sexually harassed and assaulted by powerful men in the entertainment industry. Ironically the makers of a movie that symbolized female empowerment were involved in such demeaning actions. The reason given by Uma Thurman regarding the need for her containment of her anger was: "I used the word 'anger' but I was more worried about crying, to tell you the truth," she said, "I was not a groundbreaker on a story I knew to be true. So what you really saw was a person buying time." Explaining herself as to the media persons regarding the assaults, "Personally," Thurman said, "it has taken me 47 years to stop calling people who are mean to you 'in love' with you. It took a long time, because I think that as little girls we are conditioned to believe that cruelty and love somehow have a connection and that is like the sort of era that we need to evolve out of." (Dowd).These instances of the so called "western liberalized" world dealing with the voicing of resent by women indicate that the gendering of the emotions is so strong that it will take a conscious effort on the part of the society to do away with the embedded notions of what is right or wrong for women and men.

The advertising campaign \#Man Enough by Gillette India giving out the strong message that "Men Can Cry" was one such initiative that tried to break down archaic stereotype of masculinity that "Men don't cry". The Good Men Project at https://goodmenproject.com/ is one such initiative founded in 2009 in the United States by Tom Matlack and James Houghton as a way to allow men to tell stories about the defining moments in their lives. The hope was to spark a "national conversation" around the question of "What does it mean to be a good 
